\title{
Surgical Treatment of Benign Retrorectal Masses in Adults: A Retrospective Study
}

\author{
Hüseyin Bilge', Ömer Başol' ${ }^{2}$, Abdullah Oğuz ${ }^{3}$ \\ ${ }^{1,2}$ Assistant Professor, ${ }^{3}$ Associate Professor, Department of General Surgery, Dicle University, Diyarbakır, Turkey
}

Background: Tumors that occur in the retrorectal space are called retrorectal tumors. These tumors arise from various tissues. Late symptoms may therefore outweigh diagnosis and treatment. Therefore, the surgery becomes difficult. Aims and Objectives: Our study aims to reveal the difficulties in the diagnosis of retrorectal tumors, radiological diagnostic methods, and safe surgical excision surgical techniques. Materials and Methods: Twelve patients operated for retrorectal tömür between 2014 and 2020 were included in the retrospective study. Demographic features, clinical findings, diagnostic methods, surgical treatment procedures, evaluations of preoperative/postoperative complications, pathological classifications, length of hospital stay, and duration of surgery were studied. Results: Twelve patients [9 females, 3 males; the mean age was $39.3 \pm 11.8(22-56)]$ due to retrorectal tumors. All lesions were evaluated preoperatively using magnetic resonance imaging (MRI). According to the preoperative examination and radiological findings; Surgical resection was performed with an anterior approach to 3 patients, a posterior approach to 4 patients, and a combined approach to 5 patients. The mean tumor size was $8 \pm 2.24 \mathrm{~cm}$. Immature teratoma and epidermoid cyst $(n=6)$ were the most common tumors. We did not have any patients with features of malignancy on final histopathology. Conclusion: Although retrorectal tumors are difficult to diagnose, it is important to suspect clinically. A good evaluation of the patients with radiological imaging facilitates the resection of the tumor surgically. Surgery of the patient in centers specialized in these tumors increases surgical success.

Keywords: Sacral Region; Surgical Procedure; Radiology; Immature Teratoma; Retro-rectal mass

\section{Access this article online}

Website:

http://nepjol.info/index.php/AJMS DOI: 10.3126/ajms.v12i8.37599

E-ISSN: 2091-0576

P-ISSN: 2467-9100

Copyright (c) 2021 Asian Journal of Medical Sciences

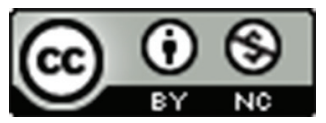

This work is licensed under a Creative Commons Attribution-NonCommercial 4.0 International License.

\section{INTRODUCTION}

Tumors that occur anatomically in the retrorectal space are called retrorectal tumors (RT). This space is limited by mesorectum in the front, presacral fascia at the back, iliac vessels and ureter at the sides, peritoneum at the top, and levator ani muscle at the bottom. ${ }^{1-3}$ These tumors can originate from various tissues. They may not be noticed for a long time because their symptoms are not clear. Therefore, it can pass diagnosis and treatment. This delay in diagnosis may cause the tumor to reach large sizes and invade vascular and neurogenic tissues. This causes intraoperative bleeding and neurological complications. ${ }^{4}$

The prevalence of these tumors is unknown, but approximately $1 / 40,000.5$ Computed pelvic tomography, magnetic resonance, and transrectal ultrasound are used for diagnosis. Surgical removal of these tumors is the most appropriate treatment method. There are some publications in the literature for surgical treatment and histological classification. An algorithm for surgical treatment was published in 2007.7 Retrorectal tumors were classified as congenital (55-65\%), neurogenic (10-12\%), osseous (5-11\%), inflammatory (5\%) and miscellaneous (12-16\%) (Table 1). ${ }^{8}$

Prospective and randomized trials are limited as RT is rarely seen clinically. The number of patients is generally limited in case series. There is no consensus on the treatment of RTs. In this study, patients diagnosed retrorectal mass treated retrospectively in our service in the last 6 years were evaluated. Demographic features, clinical findings, diagnostic methods, treatment procedures, pathology results, intraoperative and postoperative complications, and length of hospital stay were recorded. The findings 
were compared with the literature. It is of the opinion that experienced patients will undertake preoperative evaluation, surgical treatment and subsequent follow-up. In this article, we aimed to present our clinical experience to contribute to the literature.

\section{MATERIALS AND METHODS}

\section{Study design}

Patients who underwent surgery for RT at the Dicle University Medical Faculty General Surgery Clinic between January 2014 and January 2020 were included in the retrospective study. This study was approved by the Dicle University Faculty of Medicine Ethics Committe.

\section{Data collection}

Demographic features, clinical findings, diagnostic methods, treatment procedures, pathology results, intraoperative and postoperative complications, and length of hospital stay were recorded. The diagnosis was confirmed by CT or MRI in all patients. Posterior, anterior, or combined approach (anterior and posterior) was preferred as a surgical technique according to CT and MRI findings.

All patients were seen at the clinic once a month post discharge. An MRI was taken at any clinical signs of recurrence. Patients with recurrence, chronic pain and anal dysfunction were evaluated.

\section{RESULTS}

A total of 12 patients were operated on for RT. The mean age of the patients was $39.3 \pm 11.8$ years. Three of the patients were male and 9 were female. Mean tumor diameters were $8 \pm 2.24 \mathrm{~cm}$.

Most of the patients were referred from other departments such as neurosurgery and orthopedics. In most patients who came to us, the general symptom was perineal pain and tenesmus complaints. Also, patients had complaints of pelvic, sacral, low back pain, constipation, palpable perineal mass, urinary tract dysfunction, and rectal bleeding at the time of presentation (Table 2). The study was pre-approved by the Insitutional Ethical Committee.

All patients underwent an MRI examination preoperatively. Also, $9(75 \%)$ of the patients were evaluated by CT and $5(41 \%)$ patients were evaluated by proctosigmoidoscopy (Table 2).

The patients were not evaluated by biopsy before the operation. Postoperative pathological examination revealed immature teratoma in 4 patients, epidermoid cyst in 2 patients, tailgut cyst in 2 patients, and duplication cyst in one patient. In the remaining three patients, schwannoma and neurofibroma, which are neurogenic lesions, were detected (Table 3)(Figure 1-2).

Anterior approach was applied to 3 patients, a posterior approach to 4 patients(Figure 3-4), and a combined approach was applied to 5 patients. Surgical excision was performed in two patients with coccygectomy. In one patient, a separate tumor in the small intestine was detected together with a teratoma. Segmental small bowel resection was performed in patient due to mass in the small intestine simultaneously, and a diagnosis of neuroendocrine tumor was made pathologically. In tumors that extend to the sacral fascia, are close to the vascular structures, and have the ability to invade, attention should be paid to bleeding. Two patients diagnosed with teratoma had intraoperative bleeding and needed transfusion. Primary suturing was performed in one patient due to rectum injury and a protective loop ileostomy was opened. Ileostomy was closed 3 months later. Also, 1 patient developed wound infection in the postoperative period. In one patient who was operated with a combined approach, an abscess with an intra-abdominal extension of $8 * 7 \mathrm{~cm}$ was observed in the operating site. The patient was treated with percutaneous drainage and antibiotherapy. The average length of hospital stay was $16.8 \pm 7.25$ days. The operation times were on

\section{Table 1: Classification of the retrorectal tumors}

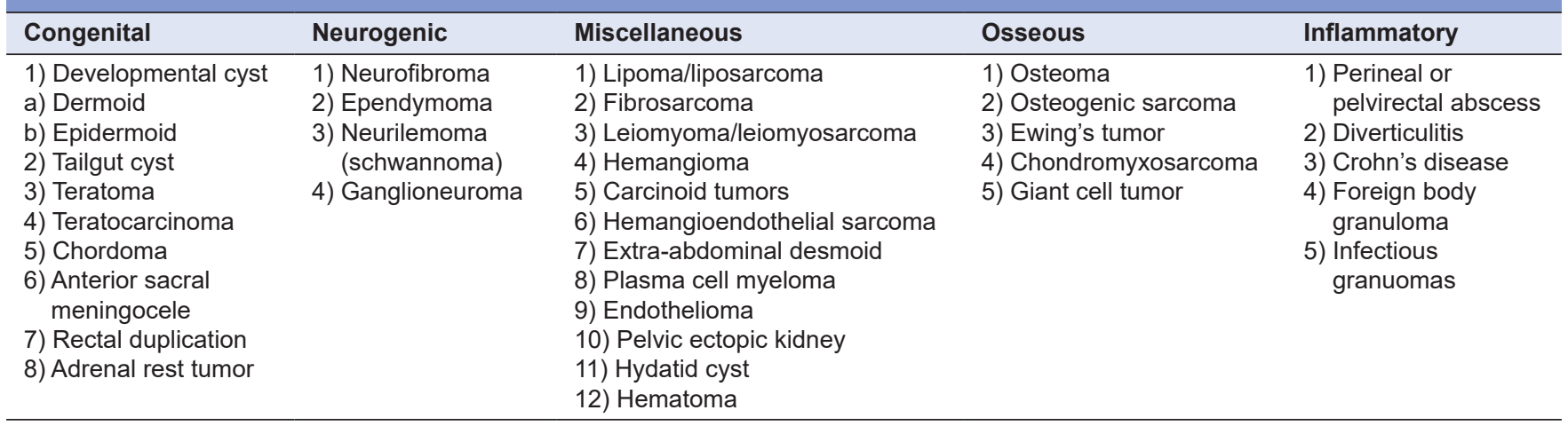




\begin{tabular}{llllll}
\multicolumn{2}{l}{ Table 2: Characteristics of patients } & & \\
\hline $\begin{array}{l}\text { Case Age } \\
\text { (years) }\end{array}$ & Gender & $\begin{array}{l}\text { Preoperative } \\
\text { symptoms }\end{array}$ & $\begin{array}{l}\text { Preoperative } \\
\text { evaluation }\end{array}$ & $\begin{array}{c}\text { Tumor diameter } \\
\text { radiologically (MR)(cm) }\end{array}$ & $\begin{array}{l}\text { Tumor } \\
\text { Location (MR) }\end{array}$ \\
\hline 32 & Female & Pelvic pain & MR/CT/RSS & $8,5 \times 4$ & Coccyx inferior \\
45 & Female & Pelvic pain and tenesmus & MR/CT & $9 \times 8$ & Presacral \\
32 & Female & Perineal pain, lump in the gluteal region & MR/CT/RSS & $5,4 \times 5,3$ & Presacral \\
53 & Female & Perineal pain & MR/CT & $3,6 \times 3,4$ & Pre-coccygeal \\
43 & Male & Perineal pain & MR/CT & $7 \times 6$ & Presacral \\
29 & Female & Rectal bleedingand Lower back pain & MR/CT & $7 \times 5$ & Presacral \\
22 & Female & Defecation difficulty, pelvic pain & MR/CT & $16 \times 13$ & Presacral \\
42 & Male & Perineal pain and lower back pain & MR/RSS & $56 \times 38$ & Coccyx inferior \\
53 & Female & Perineal pain & MR/PET & $4,4 \times 3,3$ & Presacral \\
56 & Female & Perineal pain & MR & $8 \times 6$ & Presacral \\
43 & Male & Pelvic and sacral pain & MR/CT/RSS & $7 \times 5$ & Presacral-rectorectal \\
22 & Female & Perineal pain & MR/CT & $16 \times 12$ & Presacral \\
\hline MR; magnetic resonance, BT; computed tomography, RSS; rectosigmoidoscopy, PET; Positron emulsion tomography. & &
\end{tabular}

Table 3: Findings during and after the operation

\begin{tabular}{|c|c|c|c|c|c|}
\hline $\begin{array}{l}\text { Operative } \\
\text { approach }\end{array}$ & $\begin{array}{l}\text { Intraoperative } \\
\text { complication }\end{array}$ & $\begin{array}{l}\text { Postoperative } \\
\text { complications }\end{array}$ & $\begin{array}{l}\text { Pathology and } \\
\text { Tumor diameter(cm) }\end{array}$ & $\begin{array}{l}\text { Operative } \\
\text { time (min) }\end{array}$ & $\begin{array}{l}\text { Length of } \\
\text { Stay (days)) }\end{array}$ \\
\hline Posterior & None & None & $\begin{array}{l}\text { Immature teratoma } \\
\left(5^{*} 4^{*} 2\right)\end{array}$ & 132 & 17 \\
\hline Combined & None & None & $\begin{array}{l}\text { Schwannoma } \\
(10 * 10 * 8)\end{array}$ & 352 & 20 \\
\hline Anterior & Bleeding & None & $\begin{array}{l}\text { Schwannoma } \\
\left(6,5^{\star} 6^{*} 4,5\right)\end{array}$ & 222 & 24 \\
\hline Combined & None & $\begin{array}{l}\text { Perianal fistula } \\
\text { (In the 3rd month) }\end{array}$ & $\begin{array}{l}\text { Immature teratoma } \\
\left(7,7^{\star} 6,5^{\star} 5,5\right)\end{array}$ & 160 & 13 \\
\hline Combined & $\begin{array}{l}\text { Rektum İnjury (repair with } \\
\text { suture +loop ileostomy) }\end{array}$ & $\begin{array}{l}\text { Intraabdominal } \\
\text { abscess }\end{array}$ & $\begin{array}{l}\text { Duplication cyst } \\
\left(7,5^{\star} 5,5^{\star} 5\right)\end{array}$ & 180 & 21 \\
\hline Combined & None & None & $\begin{array}{l}\text { Tailgut cyst } \\
\left(12^{*} 10^{*} 4\right)\end{array}$ & 170 & 23 \\
\hline Posterior & None & None & $\begin{array}{l}\text { Epidermoid cyst } \\
\left(7^{\star} 2^{*} 5\right)\end{array}$ & 120 & 8 \\
\hline Anterior & Nerve injury & None & $\begin{array}{l}\text { Neurofibroma } \\
\left(7,7^{\star} 5^{\star} 3,1\right)\end{array}$ & 281 & 6 \\
\hline Combined & Bleeding & Wound infection & $\begin{array}{l}\text { Immature teratoma } \\
\left(7,5^{\star} 6,5^{\star} 5,5\right)\end{array}$ & 230 & 27 \\
\hline Anterior & None & None & $\begin{array}{l}\text { Immature teratoma } \\
\left(7,7^{*} 6,5^{*} 5,5\right)\end{array}$ & 160 & 13 \\
\hline Posterior & None & None & $\begin{array}{l}\text { Tailgut cyst } \\
\left(12^{*} 10^{*} 4\right)\end{array}$ & 170 & 23 \\
\hline
\end{tabular}

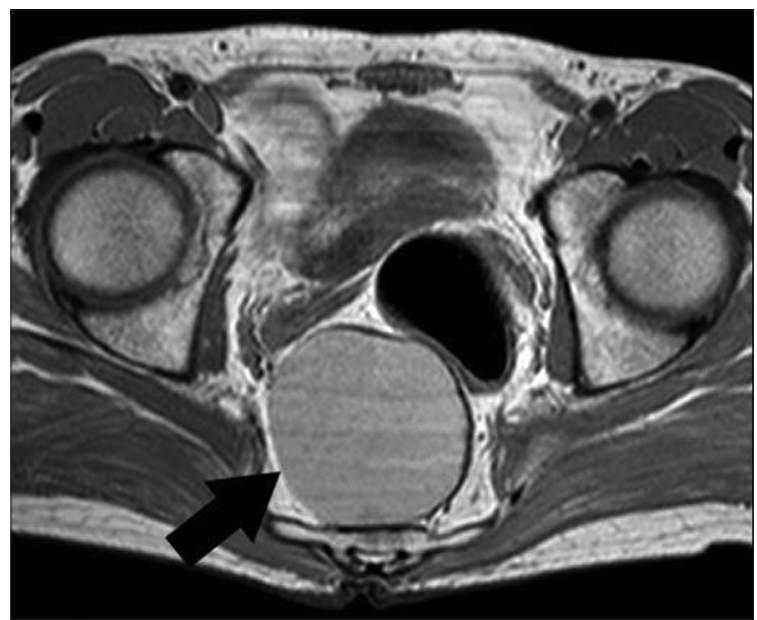

Figure 1: Axial MRI scans showing presacral immature teratoma average $193 \pm 67.6$ minutes (Table 3). No recurrence or anal dysfunction was observed during the follow-up of the patients. However, 3 patients had pain in the perianal region that lasted for about 2 months.

\section{DISCUSSION}

Retrorectal masses and presacral tumors are rare. Due to their rarity, information about the clinical, diagnostic, and imaging techniques, surgical procedures, recurrence rates, and general outcomes of these tumors are not sufficient. ${ }^{1,4}$

The incidence of reported RTs ranges from 0.9 to 6.3 per year. ${ }^{9-11}$ In this study, we detected 12 patients with retrorectal tumors for 6 years in our hospital. 


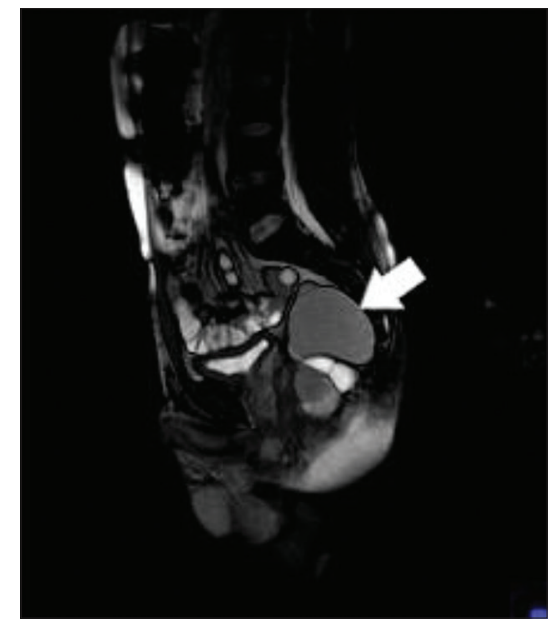

Figure 2: Sagittal MRI scans showing presacral immature teratoma

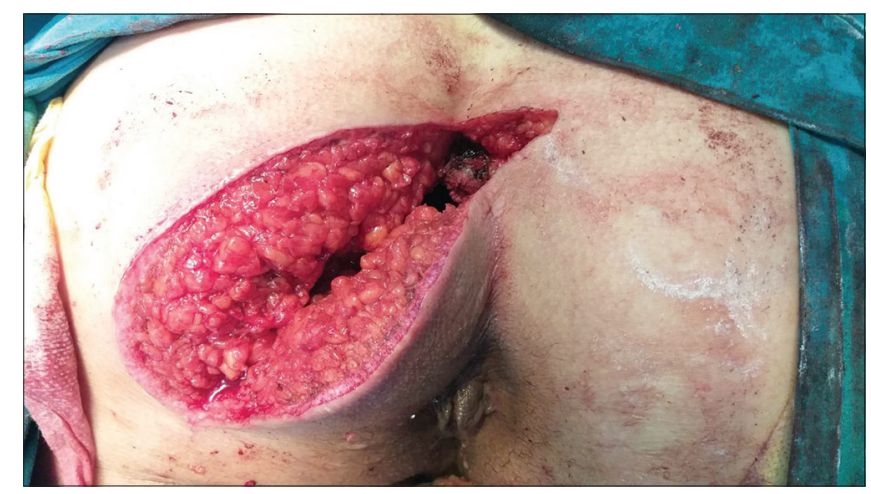

Figure 3: Posterior approach for retrorectal tumor

Congenital types are the most common of these tumors with histologically different types. Congenital types are benign and more common in women. ${ }^{10-12}$ However, epidemiologically, the importance of gender is unknown in malignant congenital RT Patients. ${ }^{1}$ In our series, it was observed that female sex was more common with retrorectal tumors $(9 / 12)$. No malign tumor was detected in our patients.

RT patients were generally asymptomatic, but they may occur with nonspecific signs and symptoms. ${ }^{2,12,13}$ The location of the tumor varies with its diameter, presence of invasion, and infection status. ${ }^{14}$ Symptomatic patients may appear as pain in the perineal region, chronic constipation, rectal or urinary incontinence, or sexual dysfunction. Some tumors cause perianal discharge. Therefore, it can be confused with perianal fistulas. ${ }^{2,15}$ Our patients complained mostly of pain in the perianal and sacral region.

Since the symptoms of the patients are not specific, it is necessary to suspect the diagnosis first. CT and MR are the gold standard for diagnosis. With CT, we can distinguish whether the mass is solid or cystic, but MR gives more valuable findings in these patients. ${ }^{4}$ In our series, 9 of our

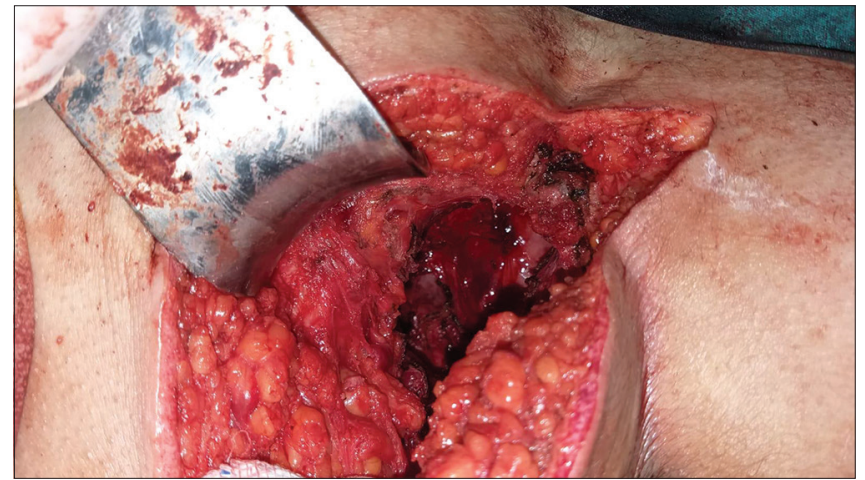

Figure 4: Postoperative lodge view

patients received $M R+C T, 2$ patients received $M R$, and one patient received MR + Scintigraphy. Scintigraphy was added to the diagnostic tests to investigate the presence of metastasis in the patient who had undergone surgery for bladder adenocarcinoma 1 year ago. No finding in favor of metastasis was found. MR was used to determine both the diagnosis and the treatment protocol to evaluate the mass before surgery.

The importance of preoperative biopsy in the treatment of RT is controversial. Bullard Dunn argued that biopsy is safe outside of the transrectal approach. ${ }^{15}$ Messick et al., suggested that we can do the biopsy to all patients. ${ }^{1}$ Ghosh et al., argued that preoperative biopsy is unnecessary, as the decision of surgery is not affected by biopsy. ${ }^{16}$ Biopsy should not be performed especially in cystic lesions. It can usually be diagnosed radiologically. However, chemotherapy and radiotherapy may be required in patients with osteogenic sarcoma and lymphoma. ${ }^{17} \mathrm{We}$ did not do biopsy in any patient, considering that biopsy results would not affect our surgical decision and cause serious complications.

RTs are divided into 5 groups with a classification made in 1949. This classification is summarized in Table 1. Congenital ones can be cystic or solid and makeup about $60 \%$ of RTs. They are more common in women and are generally benign. ${ }^{4}$ The majority of our patients (9/12) were in this group. Teratomas are true neoplasms that contain the elements of the 3 germ layers. Therefore, they contain the epithelium of the gastrointestinal, respiratory, and nervous systems. Although they are generally benign, they may have the potential for malignant degeneration. ${ }^{4,18}$ In our study, teratoma (Figure 5) was detected in 4 patients and an epidermoid cyst in 2 patients. The second frequency is neurogenic tumors. These tumors are caused by peripheral nerves and $85 \%$ of them are benign. In our series, 3 patients had neurogenic tumors, 2 of them had schwannoma and 1 had neurofibroma. There were no less common miscellaneous tumors, inflammatory tumors, and osseous tumors in our patients. 


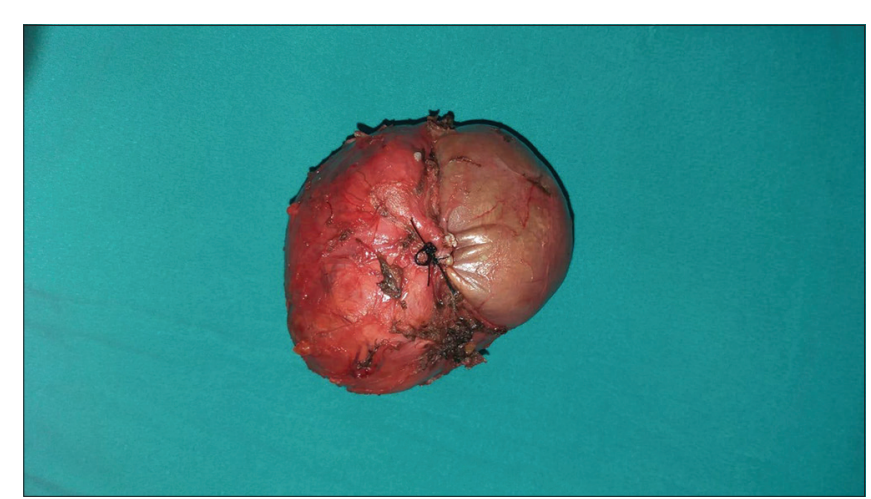

Figure 5: Immature teratoma macroscopic view

Although RTs are asymptomatic, they can cause infection and undergo malignant degeneration. Therefore, it must be fully resected surgically. The surgical approach should be planned based on the size and extent of the lesion, preoperative MRI findings, based on the surgeon's pelvic or postrecral anatomy specialization.,17,19 The anterior approach benefits the surgeon in terms of protecting intra-abdominal organs and vascular structures. It is more advantageous with anterior or combined approaches when dealing with masses that have reached a large diameter $(>$ $5 \mathrm{~cm}$ ) and are above the $\mathrm{S} 3$ level. The posterior approach is suitable for patients who are below the S3 level and whose upper limit can be reached by digital rectal examination. , $20-22^{2}$ In our study, surgery was performed with anterior to 3 patients, posterior to 4 patients, and a combined approach to 5 patients.

While performing R'T surgery, there may be intraoperative and postoperative complications. Serious bleeding can occur when large vessels or the sacral vein plexus are injured. Since two of our patients had bleeding during the operation, transfusion was needed. When bleeding occurs, while compressing is sometimes sufficient, severe bleeding that may require iliac artery ligation may occur. In our patients, first compression was applied to the bleeding in the sacral region, then simple ligation was made in the sacral region and the bleeding was stopped. Wound infection developed in one of our patients postoperatively. The patient showed improvement after antibiotic therapy.

With the development of laparoscopic surgery, laparoscopic resections were also on the agenda. In 2014, Duclos J et al., published a series of 12 cases. All patients underwent R0 resection and one patient was reported as malignant, and no recurrence was observed in their follow-up. ${ }^{23}$ Studies have shown that the laparoscopic approach has important benefits, such as smaller wounds, less postoperative pain, and facilitates excellent visualization of deep structures in the retrorectal space, which prevents vascular and nerve injuries. ${ }^{24,25}$

\section{CONCLUSION}

Retrorectal tumors are rare and have diagnostic difficulties. They usually occur with nonspecific symptoms or can be diagnosed when examining other pathologies. Doubt is essential for diagnosis. MR and CT assist in demonstrating the location of the tumor and preparing the surgical plan. In order to get a good surgical result, the joint decision of the branches of interest is important when treating these tumors. To reduce the risk of recurrence, surgery should be performed by hands experienced in pelvic anatomy and pelvic surgery.

\section{ACKNOWLEDGEMENT}

The authors take this opportunity to thank Department of General Surgery for their whole hearted support for this study.

\section{REFERENCES}

1. Messick CA, Hull T, Rosselli G and Kiran RP. Lesions originating within the retrorectal space: a diverse group requiring individualized evaluation and surgery. Journal of Gastrointestinal Surgery. 2013;17(12):2143-2152.

https://doi.org/10.1007/s11605-013-2350-y

2. Glasgow SC, Birnbaum EH, Lowney JK, Fleshman JW, Kodner IJ and Mutch DG. Retrorectal Tumors: A Diagnostic and Therapeutic Challenge. Dis Colon Rectum. 2005;48(8):15811587.

https://doi.org/10.1007/s10350-005-0048-2

3. Church JM, Raudkivi PJ and Hill GL. The surgical anatomy of the rectum- a review with particular relevance to the hazards of rectal mobilisation. Int J Colorectal Dis. 1987;2(3):158-166. https://doi.org/10.1007/BF01648000

4. Hobson KG, Ghaemmaghami V, Roe JP, Goodnight JE and Khatri VP. Tumors of the retrorectal space. Diseases of the colon and rectum. 2005;48(10):1964-1974.

https://doi.org/10.1007/s10350-005-0122-9

5. Wolpert A, Beer-Gabel M, Lifschitz $O$ and Zbar AP. The management of presacral masses in the adult. Tech Coloproctology. 2002;6(1):43-49.

https://doi.org/10.1007/s101510200008

6. Li G, Chen K, Fu D, Ma X, Sun M and Sun W. Surgical strategy for presacral tumors: analysis of 33 cases. Chin Med J (Engl). 2011;124(23):4086-4091.

7. Woodfield JC, Chalmers AG, Phillips $N$ and Sagar PM. Algorithms for the surgical management of retrorectal tumours. BJS Br J Surg. 2008;95(2):214-221.

https://doi.org/10.1002/bjs.5931

8. Lovelady SB and Dockerty MB. Extragenital pelvic tumors in women. American Journal of Obstetrics and Gynecology. 1949;58(2):215-236.

https://doi.org/10.1016/0002-9378(49)90375-0

9. Cody HS, Marcove RC and Quan SH. Malignant retrorectal tumors: 28 years' experience at memorial sloan-kettering cancer center. Dis Colon Rectum. 1981;24(7):501-506. https://doi. org/10.1007/BF02604308

10. Uhlig BE and Johnson RL. Presacral tumors and cysts in adults. Dis Colon Rectum. 1975;18(7):581-596. https://doi.org/10.1007/ 


\section{BF02587141}

11. Jao S-W, Beart RW, Spencer RJ, Reiman HM and Ilstrup DM Retrorectal tumors. Dis Colon Rectum. 1985;28(9):644-652. https://doi.org/10.1007/BF02553440

12. Stewart RJ, Humphreys WG and Parks TG. The presentation and management of presacral tumours. BJS Br J Surg. 1986;73(2):153-155. https://doi.org/10.1002/bjs.1800730227

13. Buchs N, Taylor S and Roche B. The posterior approach for low retrorectal tumors in adults. Int J Colorectal Dis. 2007;22(4):381385.

https://doi.org/10.1007/s00384-006-0183-9

14. Gordon PH and Nivatvongs S. Retrorectal tumors. In: Principles and Practice of Surgery of the Colon, Rectum, and Anus. $3^{\text {rd }}$ ed. New York: Informa Healthcare. 2007:353-368. https://doi.org/10.3109/9781420017991

15. Bullard Dunn K. Retrorectal tumors. Surg Clin North Am. 2010; 90(1):163-171. https://doi.org/10.1016/j.suc.2009.09.009

16. Ghosh J, Eglinton T, Frizelle FA and Watson AJ. Presacral tumours in adults. Surgeon. 2007;5(1):31-38. https://doi. org/10.1016/S1479-666X(07)80109-0

17. Yang BL, Gu YF, Shao WJ, Chen HJ, Sun GD, Jin HY, et al. Retrorectal tumors in adults: magnetic resonance imaging findings. World Journal of Gastroenterology. 2010;16(46):5822. https://doi.org/10.3748/wjg.v16.i46.5822

18. Hickey RC and Martin RG. Sacrococcygeal teratomas. Annals of the New York Academy of Sciences. 1964;114(2):951-957. https://doi.org/10.1111/j.1749-6632.1964.tb41015.x
19. Macafee DAL, Sagar PM, El-Khoury $T$ and Hyland $R$. Retrorectal tumours: optimization of surgical approach and outcome. Colorectal Disease. 2012;14(11):1411-1417. https:// doi.org/10.1111/j.1463-1318.2012.02994.x

20. Pidala MJ, Eisenstat TE and Rubin RJ. Presacral cysts: transrectal excision in select patients. The American surgeon. 1999;65(2):112.

21. Singer MA, Cintron JR, Martz JE, Schoetz DJ and Abcarian H. Retrorectal cyst: a rare tumor frequently misdiagnosed. J Am Coll Surg. 2003;196(6):880-886. https://doi.org/10.1016/S1072-7515(03)00133-9

22. Kye $\mathrm{BH}, \mathrm{Kim} \mathrm{HJ}$, Cho HM, Chin HM and Kim JG. Clinicopathological features of retrorectal tumors in adults: 9 years of experience in a single institution. J Korean Surg Soc. 2011;81(2):122-127. https://doi.org/10.4174/jkss.2011.81.2.122

23. Duclos J, Maggiori L, Zappa M, Ferron M and Panis $Y$. Laparoscopic resection of retrorectal tumors: a feasibility study in 12 consecutive patients. Surg Endosc. 2014;28(4):12231229. https://doi.org/10.1007/s00464-013-3312-x

24. Konstantinidis K, Theodoropoulos GE, Sambalis G, Georgiou M, Vorias M, Anastassakou K, et al. Laparoscopic resection of presacral schwannomas. Surgical Laparoscopy Endoscopy and Percutaneous Techniques. 2005;15(5):302-304. https://doi.org/10.1097/01.sle.0000183252.96808.78

25. Marinello FG, Targarona EM, Luppi CR-O, Boguña I, Molet J and Trias M. Laparoscopic Approach to Retrorectal Tumors: Review of the Literature and Report of 4 Cases. Surg Laparosc Endosc Percutan Tech. 2011;21(1):10-13. https://doi.org/10.1097/SLE.0b013e3182020e69

\section{Authors Contribution:}

HB-Concept and design of the study; prepared first draft of manuscript, Statistically analysed and interpreted, preparation of manuscript; ÖB- Interpreted the results; reviewed the literature and manuscript preparation; Concept, coordination, review of literature and manuscript preparation; AO- Statistically analysed and interpreted, preparation of manuscript and revision of the manuscript

\section{Work attributed to:}

Department of General Surgery, Dicle Üniversity, Diyarbakır Turkey, Pin: 21200

Orcid ID:

Dr. Hüseyin Bilge - id https://orcid.org/0000-0001-7203-2288

Dr. Ömer Başol - (D https://orcid.org/0000-0001-9237-4648

Dr. Abdullah Oğuz - (1) https://orcid.org/0000-0001-5840-8541

Source of Support: Nil, Conflict of Interest: None declared. 